\title{
Nottingham Grade 3
}

National Cancer Institute

\section{Source}

National Cancer Institute. Notting ham Grade 3. NCI Thesaurus. Code C138989.

Total Notting ham scores of 8 or 9. 